\title{
Suboptimal Equilibria from Nominal GDP Targeting
}

\section{Thomas L. Hogan}

Rice University

William J. Luther

Florida Atlantic University

\begin{abstract}
We use a simple model to illustrate that nominal GDP targeting might produce a suboptimal equilibrium if there is a growthmaximizing rate of inflation. Following a shock, we find that targeting nominal GDP might result in lower real GDP growth than the economy could sustainably produce given its long-run potential. Our argument does not depend on problems with forecasting or implementation. We assume the monetary authority has no trouble hitting its nominal GDP target. So long as a growth-maximizing rate of inflation exists, the suboptimal outcome results when the rule is followed.
\end{abstract}

\section{JEL Codes: E42, E52, E41, E31}

Keywords: monetary policy, nominal GDP targeting; inflation, economic growth

\section{Introduction}

In the aftermath of the Great Recession of 2007-2009, economists have revived old debates over the proper role of the Federal Reserve and whether monetary policy should be based on rules or discretion. One popular proposal is that the Fed should commit to stabilizing the path of total nominal spending. ${ }^{1}$ Rather than attempting to influence economic activity by targeting short-run interest rates or inflation, the Fed would instead manage the money supply so that nominal GDP grows at some prescribed rate, regardless of whether

\footnotetext{
${ }^{1}$ Nominal GDP targeting may be undertaken by any monetary authority such as a central bank, currency board, or even a private money-creating entity. See, for example, Salter and Young (2018). As such, we will use the term "monetary authority" in what follows.
} 
that growth results from changes in prices or from economic production. Proponents of nominal GDP targeting maintain that it would help stabilize the economy (Hendrickson 2012) and prevent asset bubbles (Beckworth 2012). Moreover, they argue that it would accomplish these tasks more effectively than inflation targeting (Beckworth 2014) or interest rate targeting (Beckworth and Hendrickson 2020). ${ }^{2}$

While enthusiasm for nominal GDP targeting has surged in recent years, the advantages of such a rule have been cited since at least the 1980s (Tobin 1983; Bean 1984; Taylor 1985; McCallum 1987; Bradley and Jansen 1989b). ${ }^{3}$ Advocates, then and now, maintain that the monetary authority cannot improve matters in the face of real shocks but can make matters better by offsetting nominal shocks. In a basic model of aggregate demand and supply, targeting nominal GDP amounts to stabilizing aggregate demand. If nominal shocks are offset by monetary policy, as is required by a nominal GDP targeting rule, the economy will not over- or underproduce in the short run (or, if monetary policy acts with a lag, will not do so for very long). Since real shocks change the natural rate of output, the economy will produce more or less than it did before. However, so long as aggregate demand is kept stable, the economy will not overor underproduce relative to the new natural rate. ${ }^{4}$ In response to nominal and real shocks, therefore, the nominal GDP target appears to be ideal.

\footnotetext{
2 Sumner (1995, 1997, 2012a, 2012b) is among the most vocal advocates of such a policy. See also Salter and Hogan (2019).

${ }^{3}$ Indeed, support for such a rule can be traced back even further. For example, Hayek (1935, p. 131) favored stabilizing what he called the "total money stream," equivalent to the product of money and velocity. See White (1999) and Hogan and White (2016).

${ }^{4}$ Under a nominal GDP targeting regime, the monetary authority's behavior in response to a real shock depends on whether changes in aggregate supply generate concurrent changes in aggregate demand. If a real shock does not affect the velocity of money, aggregate demand remains unchanged. In this case, the effects on inflation and output growth are perfectly offsetting such that no change in money growth is required of the monetary authority (Bradley and Jansen 1989a). Sumner (2012a), however, suggests that a negative supply shock often (if not always) results in a corresponding decrease in aggregate demand. He goes on to argue that greater economic damage comes from the corresponding change in aggregate demand than from the original aggregate supply shock. Regardless of the relative magnitudes, nominal GDP targeting would require the monetary authority to increase money growth following a real shock to the extent that aggregate supply shocks affect aggregate demand.
} 
The standard case for nominal GDP targeting implicitly assumes that output does not depend on the rate of inflation. If there is a growth-maximizing rate of inflation, however, then nominal GDP targeting might result in a suboptimal equilibrium, where the economy produces less than its long-run sustainable potential. In an interview (Roberts 2010), Michael Belongia notes that Milton Friedman raised such an objection with nominal GDP targeting during a lecture by then-Federal Reserve Bank of San Francisco president Robert Parry. Parry wanted to talk about nominal GDP targeting at the time and thought that 6 percent growth in nominal GDP would make sense. According to Belongia, Friedman interjected: "This is all nice, Bob, but tell me what you would do if you are at your nominal target of 6 percent but you have 7 percent on prices and minus 1 percent on real?" Friedman seems to have been suggesting that the economy would be less productive if inflation were 7 percent than it would be at some lower rate. Belongia describes this scenario as stagflation and concludes, it “doesn't take a great deal of imagination to envision we could be there a year from now-low employment, prices start to take off; housing overhang but real economy still not in good shape."

Belognia's fears have not come to fruition-perhaps because the Federal Reserve is not targeting nominal GDP, or perhaps because such fears are unwarranted. Nonetheless, the fear seems worth considering. In what follows, we use a simple dynamic aggregate supply and demand model to explain how and why the bad outcome described by Belongia (and, according to Belognia, by Friedman) might occur under a nominal GDP targeting regime. We briefly review the standard textbook treatment for nominal GDP targeting in section 2. Then, in section 3, we explain why the standard assumption that output is independent of inflation might be problematic. We question the optimality of nominal GDP targeting when that assumption is dropped in section 4. Finally, in section 5, we discuss our reservations with the simple model presented herein before offering concluding remarks.

We hope to demonstrate a potentially significant shortcoming of a nominal GDP targeting policy. Nonetheless, we remain largely in favor of the Fed adopting such a rule. Our reasoning is straightforward. No rules-based policy is perfect. By our assessment, a nominal GDP targeting policy is probably better than other rules and almost certainly better than having no rule at all. Still, advocates 
of nominal GDP targeting policy would do well to recognize its limitations. Our work serves as a first step in that direction.

\section{The Standard Case for Nominal GDP Targeting}

In this section, we consider the standard textbook treatment of nominal GDP targeting in the face of negative and positive real shocks. In doing so, we take for granted that the monetary authority is actually committing to and achieving a nominal GDP target. These assumptions are inconsistent with research on political economy, which discusses the monetary authority's lack of information and uncertainty in the execution of its duties. ${ }^{5}$ However, our purpose here is to identify an inherent problem for any nominal GDP targeting regime. As such, it is appropriate to ignore problems of implementation and institutional design. The assumption that the monetary authority successfully targets nominal GDP also allows us to limit attention to real shocks. Nominal shocks are not important for our purposes since such shocks are entirely offset by changes in the rate of money growth under a nominal GDP targeting regime.

Textbook treatments of the macroeconomy employ dynamic aggregate demand (AD) and aggregate supply (AS) curves to consider the effects of various shocks on output growth $y$ and inflation $p$ in the long run. ${ }^{6}$ A short-run aggregate supply curve is employed to consider the effects of nominal shocks when inflation expectations $p^{e}$ do not immediately adjust. Since we are only interested in the long-run effects of real shocks, however, we can ignore the short-run aggregate supply curve. Hence, we assume $p^{e}=p$.

Dynamic aggregate demand is defined as combinations of inflation $p$ and output growth $y$ for a given nominal spending growth rate $m+v$. Starting with the (static) equation of exchange, where $M V=P Y$, it is straightforward to derive an approximation of the dynamic equation of exchange: $m+v \approx p+y$. Treating the derivation as an equality and rearranging to $p=(m+v)-y$, it is

\footnotetext{
5 There is a long literature on the political economy of the Federal Reserve. Meltzer (2003) demonstrates the Fed does not fit the typical narrative of the enlightened Fed stabilizing the monetary system. Salter and Luther (2019) show that poor monetary policy decisions need not imply poor motivations on the part of central bankers. Other works, including Salter (2014) and Smith and Boettke (2015), consider the Fed in the context of robust political economy and discuss the institutional problems of limited knowledge and how poor incentives limit the Fed's effectiveness.

${ }^{6}$ See, for example, Cowen and Tabarrok (2013).
} 
clear that the slope of the dynamic aggregate demand curve in $y, p$ space is negative 1. As noted above, we assume the monetary authority has no trouble stabilizing dynamic aggregate demand. Simply put: (1) it can choose whatever rate of money growth is required to satisfy the objective, and (2) some rate of money growth exists to satisfy the objective.

The dynamic aggregate supply curve follows directly from considerations of the standard Solow model. Since output $Y$ is a function of only real factors of production like physical capital, human capital, and the level of technology, output growth $y$ depends directly on technological growth and indirectly on the accumulation of physical and human capital that accompanies technological growth. Under the standard textbook treatment, neither output nor output growth depends on the rate of inflation in the long run: $\frac{\partial Y}{\partial p}=0$ and $\frac{\partial y}{\partial p}=0$. Finally, the dynamic aggregate supply curve is commonly thought of as reflecting an economy's optimal level of long-run economic growth at a particular point in time. ${ }^{7}$

In figure 1, we depict a negative real shock using the dynamic AD/AS framework. The shock is represented by a leftward shift of the dynamic AS curve. Inflation increases from $p_{1}$ to $p_{2}$. Output growth decreases from $y_{1}$ to $y_{2}$. However, since the slope of the dynamic aggregate demand curve is equal to negative $1, p_{1}+y_{1}=$ $p_{2}+y_{2}$. Nominal GDP is unchanged. Hence, a monetary authority targeting nominal GDP will not alter $m$. Moreover, it is clear that, in this framework, the economy is neither overproducing nor underproducing. Nominal GDP targeting yields the optimal outcome.

\footnotetext{
7 More precisely, the dynamic aggregate supply curve reflects an economy's sustainable level of long-run economic growth contingent on policies in place. As such, a higher sustainable level of economic growth would be possible if policies were improved.
} 
Figure 1. Effects of a negative supply shock under the standard view

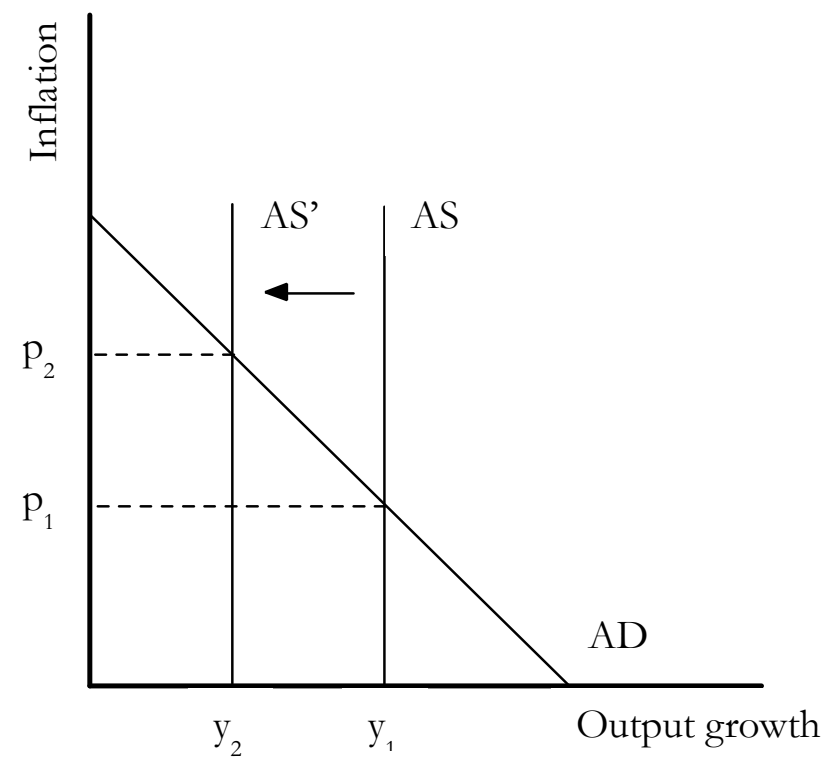

Figure 2. Effects of a positive supply shock under the standard view

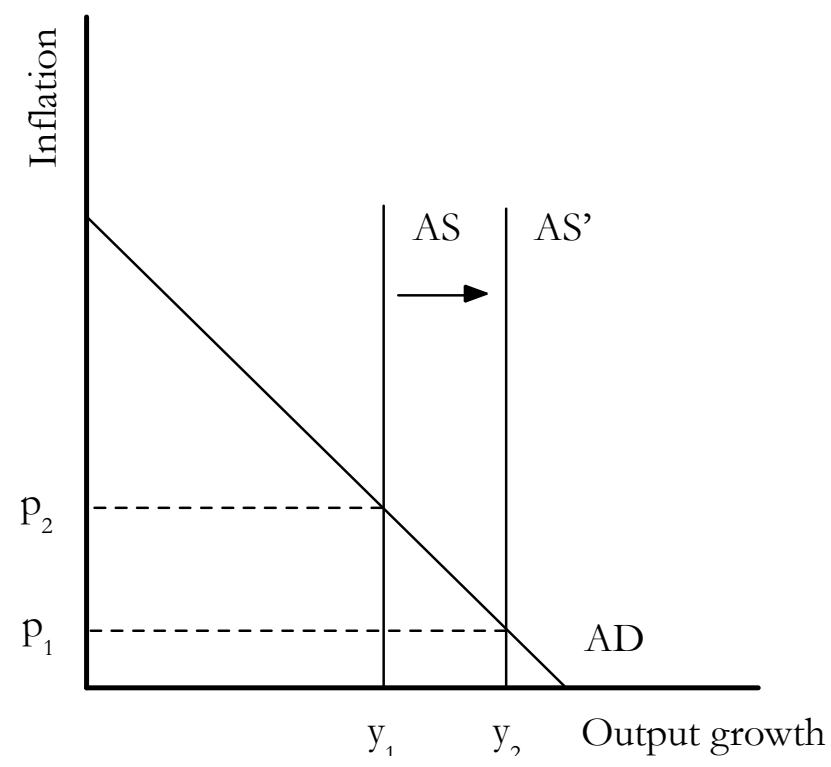


In figure 2, we depict a positive real shock using the dynamic $\mathrm{AD} / \mathrm{AS}$ framework. The shock is represented by a rightward shift of the dynamic AS curve. Inflation decreases from $p_{1}$ to $p_{2}$. Output growth increases from $y_{1}$ to $y_{2}$. As in the case of a negative real shock, $p_{1}+y_{1}=p_{2}+y_{2}$ because the slope of the dynamic aggregate demand curve is equal to negative 1 . Since nominal GDP is unchanged, a monetary authority targeting nominal GDP will not alter $m$. Again, nominal GDP targeting yields the optimal outcome. The economy is neither overproducing nor underproducing following the shock.

\section{The Case for a Growth-Maximizing Rate of Inflation}

We challenge the standard textbook assumption that output growth is independent of the rate of inflation. In contrast, we assume a growth-maximizing rate of inflation $p^{*}$. Building on the standard textbook treatment, our modification affects the dynamic aggregate supply curve. Specifically, we assume potential output growth is lower when $p<p^{*}$ and $p>p^{*}$. Given the real factors of production, $\max (y)$ is only obtainable at $p^{*}$. Moreover, we assume that $\max (y)-y_{i}$ increases as $\left|p_{i}-p^{*}\right|$ increases, where $p_{i}$ and $y_{i}$ refer to the $i^{\text {th }}$ combination of inflation and output growth on the dynamic aggregate supply curve.

The modification proposed herein amounts to the mere acknowledgement that some rates of inflation might be more costly than others. The economy as a whole produces less of everything else when it employs more resources to deal with inflation. The notion of a growth-maximizing rate of inflation might at first strike some economists as odd, since the effect of money growth on real variables is typically regarded as approximately neutral in the long run. Upon further reflection, however, this idea is relatively uncontroversial. Who would maintain that economic productivity does not suffer at an inflation rate of $+/-1000$ percent? Such frequent price changes would require more shop keepers to keep prices up to date; more currency brokers to help those trying to cash in or out of the unstable money; and so on. The more resources that are expended to deal with the extreme rate of inflation, the fewer resources that are left to produce other valuable goods and services. The view that there is some growth-maximizing rate of inflation is simply a claim that 
somewhere between these extremes, there is a rate that minimizes the costs of dealing with inflation. ${ }^{8}$

To illustrate the detrimental effects of missing the mark, one need not know precisely what the growth-maximizing rate of inflation is. One need merely accept that such a rate exists. Still, considering the three most common views on the growthmaximizing rate of inflation provides some theoretical underpinning (Luther forthcoming).

The first view maintains that the growth-maximizing rate of inflation is zero (e.g., Meltzer 1999). Advocates of such a position usually maintain that the general price level is a numeraire and, hence, any costs incurred to change the numeraire are unwarranted. Some also note that since nominal capital gains are subject to tax, inflation results in costly distortions in saving and investment.

The second view maintains that some low but positive amount of inflation is desirable (e.g., Akerlof, Dickens, and Perry 1996). This view is usually justified on the grounds of lubricating labor marketsthat is, enabling employees to accept a lower real wage without enduring the psychic costs of seeing the amount on their paychecks decrease, or enabling employers to offer lower real wages without reducing morale and, hence, labor productivity. Others more or less accept the first view but worry that conventional measures overestimate inflation. In other words, achieving zero percent actual inflation requires a slightly positive rate of measured inflation.

The third view maintains that inflation should be slightly negative (e.g., Freidman 1969). This view is usually justified on the grounds that individuals will hold insufficient cash balances when the real rate of return on currency is lower than the real rate of return on bonds of similar risk and duration. ${ }^{9}$ The solution, then, is to generate a mild deflation so that currency yields a positive real rate of return comparable to similar financial assets.

In all of these views, there is some cost (i.e., menu cost, transactions cost, shoe leather cost) to be minimized. A more general

\footnotetext{
${ }^{8}$ In contrast to our view that there is a growth-maximizing rate of inflation, some economists seem to suggest there is a growth-maximizing range of inflation. By this, they usually mean that differences in the costs of inflation are trivial over some range of inflation rates. However, even if such costs were equal over that range, it would only call into question the extent to which our argument applies, not whether it is valid.

9 For more recent considerations of the Friedman rule, see Wolman (1997) and Sanchez (2012).
} 
view would take all of these costs (and potentially others) into account. $^{10}$

Ample empirical research suggests that inflation can have negative supply-side effects. Bruno and Easterly (1998), Gillman, Harris, and Mátyás (2004), Omaya and Kan (2010), and Baglana and Yoldas (2014) find negative relationships between inflation and economic growth. In the cases of Hungary and Poland, Gillman and Nakov (2004) find Granger causality is positive from money to inflation and negative from inflation to growth. Barro (1996), Ghosh and Phillips (1998), and Omay and Kan (2010) even find a negative effect on economic growth from moderate, short-run inflation. These studies all suggest that inflation can be too high. Our approach is consistent with these results. However, we also maintain that the rate of inflation can be too low. As such, our approach is much closer to those considering an optimal rate of inflation (e.g., Feldstein 1997; Lucas 2000; Lagos and Wright 2005).

To clarify our position, we articulate the view in the following four scenarios.

1. If the rate of inflation is too high and positive $\left(p_{i}>p^{*}\right.$ and $\left.p_{i}>0\right)$, the costs incurred from increasing prices at the requisite frequency are higher than those associated with the optimal rate and unwarranted given the benefits of the respective rate.

2. If the rate of inflation is too low and negative $\left(p^{*}<p_{i}\right.$ and $\left.p^{*}<0\right)$, the costs of decreasing prices at the requisite frequency are higher than those associated with the optimal rate and unwarranted given the benefits of the respective rate.

3. If the rate of inflation is too high and negative $(0>$ $\left.p_{i}>p^{*}\right)$, the costs incurred from increasing prices at the requisite frequency are lower than those associated with the optimal rate, but the benefits are so much lower that the costs are unwarranted.

4. If the rate of inflation is too low and positive $(0<$ $\left.p_{i}<p^{*}\right)$, the costs incurred from increasing prices at the requisite frequency are lower than those associated with

\footnotetext{
10 See Aiyagari (1990), for example. One consideration often overlooked in this debate is the effect of an increase or decrease in seigniorage revenues on the deadweight loss of taxes. On optimal seigniorage collection, see Mankiw (1987), Click (1998, 2000), and Aisen (2008).
} 
the optimal rate, but the benefits are so much lower that the costs are unwarranted.

Hence, regardless of whether the optimal rate is positive or negative, the net costs are positive at any inflation rate $p_{i} \neq p^{*}$.

In the graphical analysis that follows, we assume that the tradeoff between inflation and output growth is linear and positive for $p_{i}<p^{*}$ and linear and negative for $p_{i}>p^{*}$. We assume the trade-off is linear merely for ease of exposition. This assumption does not meaningfully affect the conclusions of our analysis. One might assume, instead, that $\max (y)-y_{i}$ increases at an increasing rate as $\left|p_{i}-p^{*}\right|$ increases. Although we would be sympathetic to such a view, it would impose more than the minimum assumptions necessary to generate the stylized results outlined below.

\section{Nominal GDP Targeting in the Modified View}

Having raised the idea of a growth-maximizing rate of inflation, we return to the two shocks considered in section 2. We consider negative and positive real shocks in a model comparable to the standard textbook treatment discussed above except that, in our modified treatment, failing to hit the growth-maximizing rate of inflation is costly. For both cases, we assume that the economy is operating at its maximum sustainable potential prior to the shock.

In figure 3, we depict a negative real shock using the dynamic $\mathrm{AD} / \mathrm{AS}$ framework modified to recognize that there is some growthmaximizing rate of inflation $p^{*}$. As in the standard framework, the shock is represented by a leftward shift of the dynamic AS curve. Inflation increases from $p^{*}$ to $p_{2}$ as output growth decreases from $y_{1}$ to $y_{2}$. Since $p^{*}+y_{1}=p_{2}+y_{2}$, a monetary authority targeting nominal GDP will not alter $m$. With the standard assumption, such a policy was ideal. With a growth-maximizing rate of inflation, however, the output growth obtained following the shock under the rule is less than the maximum sustainable potential. The monetary authority could improve matters by decreasing nominal spending growth to $p^{*}+y^{*}<p^{*}+y_{1}=p_{2}+y_{2}$. 
Figure 3. Effects of a negative supply shock under the modified view

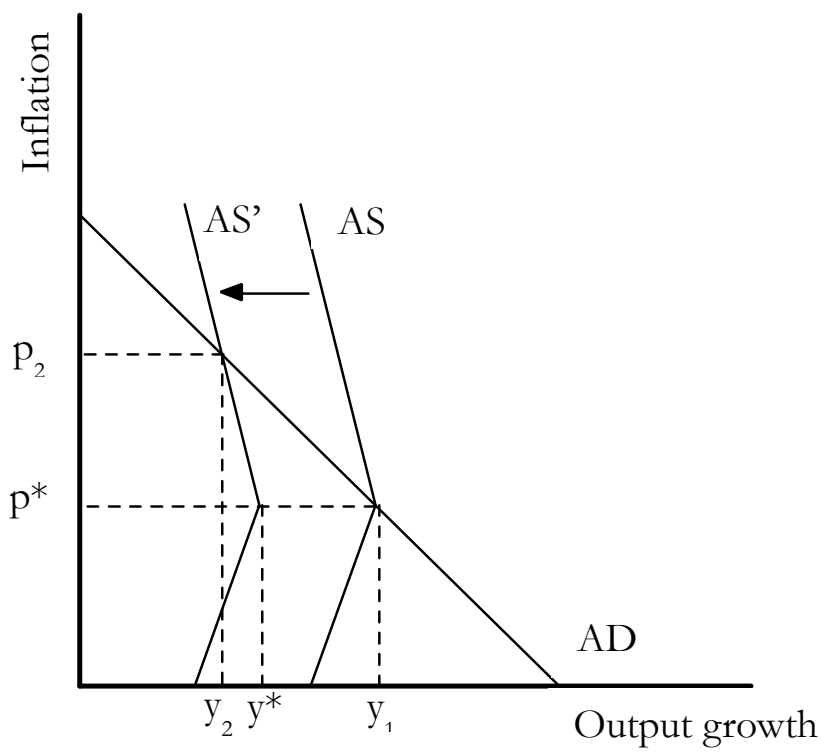

Figure 4. Effects of a positive supply shock under the modified view

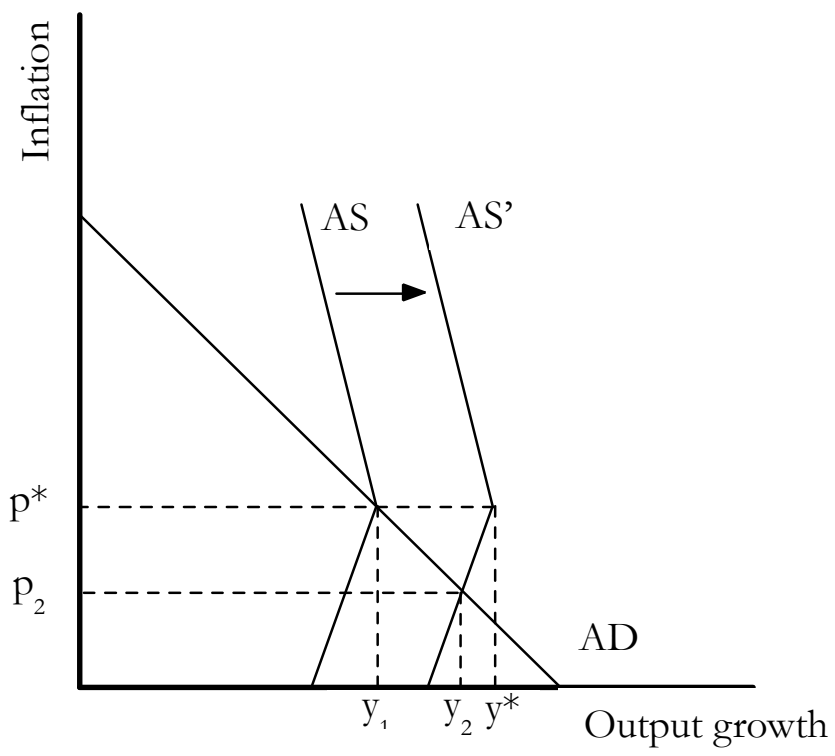


We depict a positive real shock using the same modified framework in figure 4 . Following the shock, inflation decreases from $p^{*}$ to $p_{2}$ and output growth increases from $y_{1}$ to $y_{2}$. A monetary authority targeting nominal GDP will not alter $m$ since $p^{*}+y_{1}=$ $p_{2}+y_{2}$. Again, nominal GDP targeting yields output growth that is less than the maximum sustainable potential. Increasing nominal spending growth to $p^{*}+y^{*}>p^{*}+y_{1}=p_{2}+y_{2}$ could improve matters.

In both cases considered, abandoning the nominal GDP target yields a higher rate of output growth following the shock. Economic agents in the model are neither over- nor underproducing given the nominal GDP target. However, the economy has the potential to produce more if the monetary authority were not bound by the rule. Our analysis implies that nominal GDP targeting might result in a suboptimal equilibrium. Strictly speaking, whether the result is suboptimal depends on (among other things) the relevant costs of altering $m$ and the dynamic effects of abandoning the rule. ${ }^{11}$ Still, the potential to produce more than what is possible given the rule without overproducing is not widely acknowledged by proponents of nominal GDP targeting. At a minimum, it suggests such proponents should give greater thought to the long-run costs of inflation. At most, it suggests that some other rule might be preferable to nominal GDP targeting.

\section{Conclusion}

Advocates of nominal GDP targeting have gained some ground in the last few years. Overall, we find their recommendations sensible (and generally count ourselves among them). The Federal Reserve could improve its monetary policy by following a rule that anchors long-run expectations. The rule employed should attempt to promote monetary neutrality to the extent possible. And the best way to convey commitment to a rule is to stick with it when things are not going smoothly. It is with respect to this last item that some have raised concerns about nominal GDP targeting. In particular, some fear that targeting nominal GDP in the face of negative real shocks could result in even lower potential output.

We have offered a simple model that illustrates the fears held by some critics of nominal GDP targeting. We hope our model helps facilitate conversations on the validity of such criticisms and how

\footnotetext{
${ }^{11}$ On the former, see Luther and Salter (2012).
} 
they might be addressed. In particular, we show that the underlying fear rests on the premise that there is some growth-maximizing rate of inflation, deviations from which are costly and, therefore, reduce potential output. As discussed herein, several works have found empirical support for this view. However, these works do not typically distinguish between causes of inflation or limit considerations to nominal GDP targeting regimes. It could be that changes in the rate of inflation are only harmful if they stem from monetary causes, whereas those following real shocks are altogether desirable. Indeed, this has been argued by Selgin (1997) and others. We maintain that further and more detailed empirical research is required to resolve this debate.

The current paper leaves many questions unanswered. What is the source of costs that bring about a growth-maximizing rate of inflation? Is this rate stable over time? How large are the costs of deviating from the growth-maximizing rate of inflation? Do these costs depend on expectations? How does nominal GDP targeting compare to other rules when over- and/or underproduction is possible? How robust is nominal GDP targeting to popular and political pressures on the monetary authority relative to alternative rules? These questions - and no doubt many others-would need to be answered before one could be certain that any one rule is superior to others. We hope to have provided a small step in that direction.

\section{References}

Aisen, Ari, and Francisco José Veiga. 2008. "The Political Economy of Seigniorage." Journal of Development Economics, 87 (1): 29-50.

Aiyagari, S. Rao. 1990. "Deflating the Case for Zero Inflation." Federal Reserve Bank of Minneapolis Quarterly Review, 14(3): 2-11.

Akerlof, George, William Dickens, and George Perry. 1996. "Low Inflation or No Inflation: Should the Federal Reserve Pursue Complete Price Stability?" Brookings Policy Brief, 4: 1-7.

Baglan, Deniz, and Emre Yoldas. 2014. "Non-Linearity in the Inflation-Growth Relationship in Developing Economies: Evidence from a Semiparametric Panel Model." Economic Letters, 125(1): 93-96.

Barro, Robert J. 1996. "Inflation and Growth," Federal Reserve Bank of St. Louis Review, 78(3): 153-69.

Bean, Charles R. 1984. "Targeting Nominal Income: An Appraisal." Economic Journal, 93: 806-19.

Beckworth, David. 2014. "Inflation Targeting: A Monetary Policy Regime Whose Time Has Come and Gone." Mercatus Center Working Paper, July.

Beckworth, David, and Joshua Hendrickson. 2020. "Nominal GDP Targeting and the Taylor Rule on an Even Playing Field." Journal of Money, Credit and Banking, 52(1): 269-86. 
Bernanke, Ben S. 2012. “The Federal Reserve after World War II.” Paper presented at The Federal Reserve and the Financial Crisis, George Washington University School of Business Lecture series, Washington, DC, March 22.

Bradley, Michael D., and Dennis W. Jansen. 1989a. "The Optimality of Nominal Income Targeting When Wages Are Indexed to Price." Southern Economic Journal, 56(1): 13-23.

Bradley, Michael D., and Dennis W. Jansen. 1989b. "Understanding Nominal GDP Targeting." Federal Reserve Bank of St. Louis Review (November/December 1989): 31-40.

Brunoa, Michael, and William Easterly. 1998. "Inflation Crises and Long-Run Growth." Journal of Monetary Economics, 41(1): 3-26.

Calomiris, Charles W. 2009. "Financial Innovation, Regulation, and Reform." Cato Journal, 29(1): 65-91.

Click, Reid W. 1998. "Seigniorage in a Cross-Section of Countries." Journal of Money, Credit and Banking, 30(2): 154-71.

Click, Reid W. 2000. "Seigniorage and Conventional Taxation with Multiple Exogenous Shocks." Journal of Economic Dynamics and Control, 24(10): 1447-79.

Cowen, Tyler, and Alex Tabarrok. 2013. Modern Principles: Macroeconomics. 2nd ed. New York: Worth Publishers.

Feldstein, Martin. 1997. "The Costs and Benefits of Going from Low Inflation to Price Stability." In Reducing Inflation: Motivation and Strategy, ed. Christina D. Romer and David H. Romer, 123-56. Chicago: University of Chicago Press and NBER.

Friedman, Milton. 1969. "The Optimum Quantity of Money." In The Optimum Quantity of Money and Other Essays. Chicago: Aldine.

Ghosh, Atish, and Steven Phillips. 1998. "Warning: Inflation May Be Harmful to Your Growth.” International Monetary Fund Staff Papers, 45(4): 672-710.

Gillman, Max, Mark N. Harris, and László Mátyás. 2004. "Inflation and Growth: Explaining a Negative Effect." Empirical Economics, 29(1): 149-67.

Gillman, Max, and Anton Nakov. 2004. "Granger Causality of the InflationGrowth Mirror in Accession Countries.” Economics of Transition, 12(4): 653-81.

Hayek, Friedrich A. 1935. Prices and Production. 2nd ed. London: Routledge.

Hendrickson, Joshua R. 2012. "Nominal Income Targeting and Monetary Stability." In Boom and Bust Banking: The Causes and Cures of the Great Recession, ed. David Beckworth, 257-90. Oakland, CA: Independent Institute.

Hogan, Thomas L., and Lawrence H. White. 2016. "Hayek, Cassel, and the Origins of the Great Depression." George Mason University Department of Economics Working Paper No. 16-41.

Leduc, Sylvain, Keith Sill, and Tom Stark. 2003. "Self-Fulfilling Expectations and the Inflation of the 1970s: Evidence from the Livingston Survey," Federal Reserve Bank of Philadelphia Working Paper No. 02-13/R.

Lucas, Robert E. 2000. "Inflation and Welfare." Econometrica, 68(2): 247-74.

Luther, William J. Forthcoming. "Four Principles for a Base Money Regime.” Cato Journal.

Luther, William J., and Alexander William Salter. 2012. "Monetary Equilibrium and Price Stickiness Reconsidered: A Reply to Bagus and Howden." Review of Austrian Economics, 25: 263-69.

Mankiw, N. Gregory. 1987. "The Optimal Collection of Seigniorage: Theory and Evidence." Journal of Monetary Economics, 20(2): 327-41. 
McCallum, Bennett T. 1987. "The Case for Rules in the Conduct of Monetary Policy." Federal Reserve Bank of Richmond Economic Review (September/October 1987): 10-18.

Meltzer, Allan H. 1999. "Commentary: Monetary Policy at Zero Inflation." In New Challenges for Monetary Policy, 261-76, Kansas City, MO: Federal Reserve Bank of Kansas City.

Omay, Tolga, and Elif Öznur Kan. 2012. "Re-Examining the Threshold Effects in the Inflation-Growth Nexus with Cross-Sectionally Dependent Non-Linear Panel: Evidence from Six Industrialized Economies.” Economic Modelling, 27(5): 996-1005.

Roberts, Russ. 2010. "Belongia on the Fed." Econtalk podcast with Michael Belongia. Econtalk.org, January 11.

Salter, Alexander William. 2013. "Not All NGDP Is Created Equal: A Critique of Market Monetarism." Journal of Private Enterprise, 29(1): 41-52.

Salter, Alexander William. 2014. "Is There a Self-Enforcing Monetary Constitution?" Constitutional Political Economy, 25(3): 280-300.

Salter, Alexander William, and Thomas L. Hogan. 2019. "Expectations and NGDP Targeting: Supply-Side Problems with Demand-Side Policy." Journal of Private Enterprise, 34(3): 89-106.

Salter, Alexander William, and William J. Luther. 2019. "Adaptation and Central Banking." Public Choice, 180(3-4): 243-56.

Salter, Alexander William, and Andrew T. Young. 2018. "Would a Free Banking System Stabilize NGDP Growth?" Quarterly Review of Economics and Finance, 70: 21-25.

Sanches, Daniel. 2012. “The Optimum Quantity of Money.” Federal Reserve Bank of Philadelphia's Business Review, Q4: 8-15.

Selgin, George A. 1997. Less Than Zero: The Case for a Falling Price Level in a Growing Economy. London: Institute for Economic Affairs.

Smith, Daniel J., and Perter J. Boettke. 2015. "An Episodic History of Federal Reserve Independence.” Independent Review, 20(1): 99-120.

Sumner, Scott. 1995. "The Impact of Futures Price Targeting on the Precision and Credibility of Monetary Policy." Journal of Money, Credit and Banking, 27(1): 89_ 106.

Sumner, Scott. 1997. "Reply to Garrison and White." Journal of Money, Credit and Banking, 29(4): 542-45.

Sumner, Scott. 2012a. "How Nominal GDP Targeting Could Have Prevented the Crash of 2008." In Boom and Bust Banking: The Causes and Cures of the Great Recession, ed. David Beckworth, 129-64. Oakland, CA: Independent Institute.

Sumner, Scott. 2012b. "The Case for Nominal GDP Targeting." Mercatus Center Working Paper, October 23.

Sumner, Scott. 2013. "Money Matters.” The Money Illusion, March 16.

Taylor, John B. 1985. "What Would Nominal GNP Targeting Do to the Business Cycle?” Carnegie-Rochester Conference Series on Public Policy (Spring 1985): 61-84.

Taylor, John B. 2008. "The Financial Crisis and the Policy Responses: An Empirical Analysis of What Went Wrong." Presented at a conference in honor of David Dodge, former governor of the Bank of Canada, Ottawa, Canada, November 14.

Tobin, James. 1983. "Monetary Policy: Rules, Targets, and Shocks." Journal of Money, Credit and Banking, 15(4): 506-18. 
White, Lawrence H. 1999. "Hayek's Monetary Theory and Policy: A Critical Reconstruction." Journal of Money, Credit and Banking, 31(1): 109-20.

White, Lawrence H. 2008. "How Did We Get into This Financial Mess?" Cato Briefing Papers No. 110, November 18.

White, Lawrence H. 2009. "Federal Reserve Policy and the Housing Bubble." Cato Journal, 29(1): 115-25.

Wolman, Alexander L. 1997. "Zero Inflation and the Friedman Rule: A Welfare Comparison.” Federal Reserve Bank of Richmond Economic Quarterly, 83(4): 1-21. 